\title{
Research on Teaching Mode Construction of ESP Course for Textile Engineering Based on Production-oriented Approach
}

\author{
Jinzhu Zhang \\ School of Humanity, Tianjin Polytechnic University, Tianjin, China
}

\begin{abstract}
In order to overcome the disadvantages of "separation of learning and using" in foreign language teaching in China, Professor Wen Qiufang and her team have put forward their theoretical and practical achievements of POA (Production-oriented Approach) after more than ten years of research and exploration. The Production-oriented Approach conforms to the reality of foreign language teaching in China in the aspects of teaching concepts, teaching hypothesis, and teaching process jumps out of the dilemma of needs analysis and passes through the theory of second language acquisition and the practice of foreign language teaching. It has profound theoretical and practical guiding significance for language teaching at colleges and universities in China. This paper, based on the introduction of POA theory and the current ESP teaching research achievements in China, combining with the practice of English ESP teaching for majors of textile engineering at Tianjin Polytechnic University, attempts to construct a set of feasible ESP teaching mode for the major of textile engineering based on POA (Production-oriented Approach).
\end{abstract}

Index Terms-POA, ESP teaching, textile engineering majors, ESP teaching mode construction

\section{INTRODUCTION}

Textile engineering is an important professional division in the higher education system of China, which has made great contributions to the training of textile talents and the development of the national textile industry. It has also made indelible contributions to the development of national foreign exchanges reserves and international trade for a long time. However, under the new situation, the textile industry in China is facing great challenges from many aspects at home and abroad, which objectively forces the talent training system of textile colleges and universities in China to reform in order to adapt to the changing situation at home and abroad under the situation of informatization and internationalization. At present, there are more than 15 colleges and universities featured with the major of textile engineering in China. In 2018, the Ministry of Education announced the list of double first-class colleges and universities, and two universities, Donghua University, and Tianjin Polytechnic University were listed in the "double first-class" disciplinary construction. With the gradual deepening and promotion of "double first-class" construction, the reform of talent training system and curriculum construction is also gradually deepening. College English teaching, as an important part of the international talent training system, is also facing important development opportunities and great challenges. How to better support the cultivation of international talents in the field of language teaching and language service is an important and critical topic that requires every college English teacher involved to study urgently. Based on Professor Wen Qiufang's POA teaching theory, combined with the college English teaching reform under the Double First-class disciplinary construction project of textile engineering at Tianjin Polytechnic University, this paper takes the ESP teaching of textile engineering as a breakthrough, and probes into how to construct a new teaching mode of ESP for the major of textile engineering in order to contribute to the cultivation of students' language ability under the background of a broader sense of textile engineering.

\section{LITERATURE REVIEW}

\section{A. An Analysis of the Present Situation of College English Teaching}

At present, English teaching in China is at the crossroads of reform. Since the reform and opening up of China in the 1970s, international exchanges have become more and more frequent, and the social expectation of college students' English application ability is getting higher and higher. College English teaching has been criticized for "the separation of learning and using" and its time-consuming and inefficient teaching. The voice of compressing in-class teaching hours and reducing the credit has been constantly heard nationally, and some universities have made it a reality. As the basis of college English, middle school English teaching is also undergoing various reforms, and the socialization of college entrance examination has opened the prelude to the reform of English teaching system.

The implementation of any teaching activity must be based on needs analysis, which is an important guarantee of the effectiveness of the teaching effect (Wang, 2004). The theory of curriculum theory also points out that there are three bases for formulating and revising curriculum objectives: students' development needs, social development needs and 
disciplinary development needs. Students' demands have diversified obviously along with the polarized English levels among freshmen, and the gap of high-level foreign language talents needed by Chinese enterprises to be globalized is also widening (Zhao, 2017). The EFL concept, which has always been followed in English teaching, basically takes British English and American English as the criteria for evaluating learners' success or failure, while neglecting the effectiveness and ideological nature of communication, resulting in low learning efficiency.

In recent years, with the cross-border integration of big data, cloud computing, Internet of things and mobile Internet, human life has entered the Internet era. At the same time, college English teaching is also greatly influenced by the Internet. The Internet provides a broader ecological environment and richer ecological elements for English education (Ye, 2017). Meanwhile, the traditional teacher-student relationship has also been subverted by Internet education. The flipped classroom can reflect the advantages of mixed learning, and help to build a new type of teacher-student relationship, which is a way to promote the effective use of resources (He, 2014). Among many media, Wechat has become an important education medium in the era of the Internet plus. More than $85 \%$ of students spend an hour a day on Wechat, $78 \%$ of students use Wechat as a learning tool; more than $65 \%$ of students develop the habit of learning English on Wechat (Chen, 2016). Sun Xianhong (2017) explores the ESP flipped classroom design from the perspective of multi-literacy training and tries to construct the ESP flipped classroom teaching mode based on the multi-literacy training framework, and proves its feasibility and effectiveness through empirical research.

At the same time, the Massive Open Online Courses (MOOCs) has attracted wide attention in the international arena, becoming a hot topic in the field of education, widely used in the field of college English teaching, has increased the interest and diversity of language teaching.

However, even if a variety of teaching modes and methods emerge in an endless stream, the challenges facing college English teaching are still obvious. Wen Qiufang (2012) believes that the current college English teaching cannot meet the three levels of needs: student development needs; social development needs, subject development needs. As a result, the division of foreign language proficiency among freshmen has been intensified, and high-level foreign language talents with international perspectives are seriously deficient. Liu Chongxin (2016) conducts a questionnaire survey of 6,000 undergraduate students and graduates on the learning needs and the effectiveness of college English teaching. The results show that more than $60 \%$ of the subjects believe that the college English class does not help to improve their English ability, the teaching mode is dull and the teaching efficiency is low.

\section{B. POA Teaching Concept}

Numerous English education experts and professors have long been committed to solving the problems in the traditional college English teaching modes in China, and have achieved greatly. The college English teaching concept and teaching mode have been greatly improved. Various distinctive teaching concepts and patterns emerge endlessly, which has achieved satisfactory results and has been proved effective in teaching practice. All these achievements are helpful to solve the fundamental problem of "what to teach and how to teach", which is a fundamental problem in the reform of college English teaching in China. It has greatly stimulated the teaching motivation of "facing the society, integrating into the society, serving the society", which is more helpful to break the backward cultivation tradition of college English teaching and high self-enclosure of the field.

At present, among these new teaching concepts and modes, POA developed by Professor Wen Qiufang's team is a sound teaching mode with the complete theoretical system, which is characterized by easy acceptance by teachers and students, and good feedback in teaching practice. Prof. Wen Qiufang, from China's Foreign Language Education Center of Beijing Foreign Studies University, leads the research group to propose a series of educational theories with Chinese characteristics. POA is one of the most influential achievements of the research group. the theoretical system and implementation path of POA has been basically formed after ten years of research and numerous teaching practices by Professor Wen's team.

The POA theoretical system consists of three parts: concept (learning-centered theory, learning integration, whole-person education), hypothesis (production-driven, input facilitation, selective learning) and teacher-mediated teaching process (driving force, promotion, evaluation) (Wen, 2015). Compared with the existing western teaching theories, the "prescription of traditional Chinese medicine" issued by POA for the "separation of learning and using" is both clearly targeted and systematic. The purpose is to enable students to "learn through using, use by learning, and achieve through learning" (Wen, 2017). POA concept, covering all aspects of teaching (driving-promoting-evaluating), is systematically interlocked among each procedure and is plausible for teachers to implement teaching practice.

POA consists of three parts. Teaching concept in the first part serves as guiding ideology for the teaching, and hypothesis in the second part and the teaching process in the third part determine the general direction and overall goal of the classroom teaching. The specific POA theoretical system is shown below: 
TABLE 1: PROFESSOR WEN's POA THEORETICAL SYSTEM (WEN, 2014)

\begin{tabular}{|l|c|}
\hline \multicolumn{1}{|c|}{ Tevels } & Production-oriented Approach 1: PROFESSOR WEN'S POA THEORETICAL SYSTEM (WEN, 2014) \\
\hline Teaching Concept & $\begin{array}{c}\text { Learning-centered; } \\
\text { Learning-using combined; } \\
\text { Whole-person education; }\end{array}$ \\
\hline Teaching Hypothesis & $\begin{array}{c}\text { Input-driven; } \\
\text { Input-motivated; } \\
\text { Selective learning; } \\
\text { Teaching procedures }\end{array}$ \\
& Learning through evaluation; \\
\hline
\end{tabular}

\section{Literature Review of ESP Teaching Research}

Teaching content is the main medium for teaching activities and students to acquire knowledge. What to teach and how to teach is a fundamental issue in the reform of English disciplines and college English teaching (Wang, 2010). CBI (content-based instruction) and ESP (English for special purposes) are the reform direction of college English teaching content, which can achieve the goal of "knowledge construction, thinking training and English skills improvement" (Sun, 2011). At the same time, college English teaching in different types of colleges should have their own characteristics, avoiding the "one-size-fits-all" teaching modes, and generating power through unleashing its own university specialty (Kong, 2014).

ESP teaching has become the development direction of college English teaching reform (Cai, 2018). Cai Jigang and Chen Yuyang (2013) conduct a questionnaire survey among students from 24 universities in Shanghai and find that nearly $80 \%$ of new students choose to use English as a tool to learn and exchange professional information and enhance their international communication skills in their own fields. 60\% of freshmen have targeted college English learning in "the ability to improve their disciplinary learning in English (such as: having access to academic literature in English, listening to lectures and presentations, etc.)". More than $83 \%$ of freshmen hope to "read the English academic literature".

Cai Jigang (2015) believes that ESP teaching is the only effective way to continue to improve students' English proficiency at the university levels. Yang Feng (2013) believes that: under the premise of ensuring the core position of general English teaching, each university and college should cautiously decide whether to open ESP courses according to the levels of school running, the type of personnel training, the professional requirements, employment needs, and ESP teaching resources. Wang Junkai (2015) studies the application of educational information technology in ESP teaching. Liu Mei (2013) studies and explores the continuum model of college English teaching based on ESP curriculum system, in which, basic English, general English, and ESP courses are integrated into one, taking into account many factors such as teachers, students, tasks, and the environment in teaching. Guo Yanling (2015) discusses the role of ESP teachers from the perspective of teacher professional development. Ren Rongzheng (2012) uses the $5 \mathrm{~W}+1 \mathrm{H}$ analysis method and analyzes the factors, such as purpose, content, method, teacher, task and other factors of ESP teaching based on the teaching practice of Western Medicine English. Wu Wenquan (2014) studies and explores the ESP teaching based on "MOOC Phenomenon".

The experts and scholars above have carried out analysis and research on the feasibility of ESP teaching, the concept of ESP teaching mode and many factors in teaching. There is strong guidance for future ESP teaching research, but little research and discussion is done based on a certain professional direction. Moreover, the research puts forward conceptual guidance on the teaching and development of the curriculum from a macro perspective, but the discussion is not enough from the micro-operational level.

Based on the author's ESP teaching practice of textile engineering and many other factors such as environment and evaluation mechanism considered, this paper attempts to construct a practical ESP teaching mode for textile engineering by taking POA (Production-Oriented Approach) research achievements as the theoretical foundation, combining with the actuality of the university's English curriculum reform in textile engineering, thus to explore a feasible way for ESP teaching of engineering majors.

\section{ReSEARCH DESIGN}

In this part, the author intends to construct an ESP teaching mode of textile engineering based on POA.

\section{A. Analysis of Related Factors}

The construction of any teaching mode must be based on the consideration of relevant factors that affect teaching production. Then, it is expected to seek an effective balance between the variables, and ultimately achieve an effective output. ESP teaching is no exception. This paper analyzes the relevant factors from the aspects of needs analysis, general English courses, and major characteristics.

1 Students' Needs Analysis 
To decide whether the teaching mode and teaching method are appropriate, the most important factor is to judge whether it can meet the students' learning needs (Liu, 2016). The implementation of any teaching activities must be based on the needs analysis, which is an important guarantee for the effectiveness of teaching effectiveness (Wang, 2004). College English teaching is bound to go without a trace if one fails to understand, reflect and meet the demand (Kong, 2014). It can be seen that the analysis of learner needs is the first step in formulating all teaching modes, and it is also the necessary condition for testing whether the teaching mode is effective or not.

However, the author believes that the analysis of college students' English learning needs should also be cautious and rational. Cai Jigang (2010) believes that the objects of needs analysis should be placed at both ends of English learners and English speakers because students' needs have certain blindness and short-sighted utilitarianism. This kind of blindness can't be attributed to the students themselves. Under the long-term test-oriented education mechanism, many students are susceptible to get used to the test-driven force as the basic and only driving force for language learning. Liu Chongxi (2016) conducts a questionnaire survey of 5,692 undergraduate and graduate students on their learning needs. The research results show that "examination needs" accounts for the highest proportion, more than $70 \%$. In terms of English ability and skill demand, the demand for listening ability is higher than other items. The author analyzes that listening comprehension in the academic tests occupies a considerable proportion regardless of the standardized test at home and abroad.

As part of the ESP teaching mode research, the author designs a questionnaire on three aspects: English learning motivation, demand status and language ability that one hopes to improve. The author did a survey of 260 undergraduate students in the School of Textile Engineering at Tianjin Polytechnic University. Among the 260 respondents, 172 students belonged to the College English Class (the 3rd level of college English), and the remaining 88 students, who had successfully passed the CET Band $4 \& 6$ in advance, belonged to classes of the optional English courses for the advanced levels. The results of the questionnaire for 172 students showed that "English for examination needs" took the highest proportion of learning, 89.5\%; the second was personal literacy, which was $35.6 \%$; the last was the career development needs with the only proportion of $26.4 \%$.

The result shows: Firstly, for students with relatively weak English proficiency, the exam is still the first driving force, and more students cannot see the connection between English and future career development, cannot see the future career development that language learning can bring; secondly, Cai Jigang (2010) believes that ESP course teaching is to help students develop their abilities of reading academic literature, listening, speaking and speaking skills required for the full-English programs. However, the cultivation of this ability should be based on the basic situation of students' English, otherwise, it will lead to low production and low efficiency.

The other 88 questionnaires showed completely different results: "their career development needs" accounted for the highest proportion of $87.9 \%$; "personal literacy increase" was the second place with $67.5 \%$; "exam needs" accounted for the lowest proportion of $34.2 \%$; in terms of "the ability that are hoped to improve", the highest proportion was expression ability, accounting for $84.5 \%$; which was followed by "academic literature reading and specialized English learning”, accounting for $64.7 \%$. This result shows that:

I. students with good English foundation are more likely to connect their own development with English learning in the future. The demand for academic development is the first motivation for English learning, and students have expanded their disciplinary vision through English learning to enhance their future career. The demand for development;

II. In non-key universities such as Tianjin Polytechnic University, the teaching of ESP courses must be proceeded from reality and with certain requirements for the student foundation, the $2^{\text {nd }}$ year should be the best teaching period when students have successfully pass the CET Band 4 \& 6.

III. Time-consuming and inefficient college English teaching must be changed. For all undergraduates, the basic English courses for the preparation of the 4th and 6th grades can no longer meet the students' individualized language learning needs, nor can they meet the goal of international talent training. CBI (content-based instruction) and ESP (English for specific purposes) presently are the reform direction of English teaching content in colleges and universities (Sun, 2011).

2 Analysis of ESP Course Content

Kong Deliang (2014) believes that ESP textbooks should be based on specialized content, which can shorten the distance between college English and students' majors so that students can truly feel the roles of college English to acquire specialized knowledge and generate English learning motivation. However, a real ESP teaching, in essence, is language ability teaching rather than content teaching (Cai, 2010). At present, a large number of specialized English textbooks from domestic publishers attempt to systematically introduce the subject contents of certain specialty, which is not a true ESP textbook. Such textbooks scare off a large number of college English teachers who are willing to engage in ESP teaching, making them think that "ESP teaching is a bilingual course teaching, which should not be taken up by college English teachers (Yin, 2011). The key to successful ESP is language learning skills rather than their specialized skills, which is the most lacking of students and the focus of ESP teaching (Jordan, 1997). Therefore, Cai Jigang (2014) believes that ESP classroom teaching should focus on language skills rather than disciplinary knowledge. Language teachers can be competent in ESP teaching as long as they have some basic knowledge in terms of professionalism. Therefore, the content of ESP classroom teaching should be academic lectures, explanatory texts and 
academic literature related to the academic background of students. It is believed that the way to test the effects of learning can be diversified, such as the writing of literature review, abstracts writing, oral reports and essays, etc., which would be helpful to achieve the initial goals in using English to 1) listen to English academic lectures; 2) read academic literature in English; 3) write academic articles in English; 4) give oral reports and discussion in academic activities (Wen, 2014).

Textile engineering in Tianjin Polytechnic University is aimed at cultivating modern textile talents with an international vision. It has set up five specialty directions: 1. Textile Science and Technology; 2. Textile Design and Application; 3. Textile and Clothing Trade; 4. Textile Business and Textile Inspection; 5. Knitting and Clothing.

At present, college English teaching at the university adopts the combination of general English plus English optional skills development courses. The latter courses are generally targeted for students who have passed the CET Band-4. Subject to the shortage of teachers, these courses are limited to courses such as Audio-visual English, communicative oral English, and selective English newspaper reading, etc., all of which are designed to improve English language proficiency. According to the statistics on satisfaction degree of the courses in the survey, $27.5 \%$ of the students surveyed expressed satisfaction with the courses, and $67.7 \%$ of the students thought that the courses did not help the English ability improvement and specialty study, and just help to obtain credits and complete the course study; $75.6 \%$ of respondents believe that courses such as academic literature reading that is helpful for academic learning should be offered.

With the advancement of college English teaching reform in China, based on the author's investigation and research and the needs of the school's "double first-class" construction, the author believes that the establishment of ESP curriculum is the general trend and the inevitable demand for cultivating professionals with an international vision.

3 Analysis of the Leading Role of Teachers

Due to the influence of Western teaching theories, the role of teachers has been marginalized in the past 20 years (Wen, 2014). Teachers are only seen as facilitators, consultants, and helpers. POA believes that in addition to providing support and help for teachers, it is more important for teachers to play a leading role in the entire teaching process. Teachers should be the designers, organizers, leaders, and commanders of classroom teaching. Students are the main body of learning activities. Teachers can't replace students' learning, but in classroom learning, teachers play a leading role in how to make students actively participate in effective learning. In ESP classroom teaching, the leading role of teachers and the main role of students should be fully reflected and played. As a deepening and extending of students' academic learning, ESP is a huge challenge for both students and teachers. In ESP teaching, emphasis on the leading role of teachers does not necessarily mean to deny the subject status of students, but to give full play to the professional leading role of teachers. To maximize learning achievements, the professionalism and teaching experience of English teachers should be responsible for the quality of teaching.

At present, the research on the role of teachers in ESP teaching in China is still insufficient. Hu Pingping (2016) conducts a case study on the role of teachers in implicit courses. This study has a certain revelation and implication on the role of teachers in ESP classrooms and teaching methods. Zheng Yuqi (2014) studies the role of teachers in foreign language teaching in the post-method era. He points out that foreign language education in China has entered the post-method era, where a traditional knowledge transfer is no longer the main task of teachers. The teachers provide timely assistance when students need help, serving as the monitor, guide of teaching activities and the facilitator of meaning construction.

\section{Teaching Effectiveness Evaluation of ESP Courses}

Teaching evaluation has always been an indispensable part of foreign language curriculum construction. However, for a long time, the evaluation of teaching effectiveness has not received enough attention. The curriculum evaluation mechanism directly affects the effect of students' participation in classroom learning. The flexible and effective learning evaluation mechanism can motivate learners' subjective learning motivation and better participate in classroom learning activities. However, due to the long-term impact of exam-oriented education, learning assessment has always been an important criterion for measuring teaching evaluation, and sometimes even the only criterion, that is, the teaching effect is completely measured by the final evaluation results of students. Fang Xiucai (2017) constructs a framework for effective evaluation of foreign language teaching in the information age. He expands Danielson's (2013) scale into four dimensions, namely: planning and preparation; classroom teaching; teaching responsibility; second classroom extension. The effectiveness of teaching is discussed through the teacher's teaching logs, students' assessment forms, questionnaires, teacher-student interviews, and other forms.

In terms of student performance evaluation, quantitative scores are no longer the only criteria. Class participation, curiosity, and critical thinking skills demonstrated by students in the ESP class are important evaluation scales; small papers and oral reports are also the main manifestations of the ESP classroom learning evaluation mechanism. At the same time, teacher-student mutual evaluation and peer-to-peer evaluation are different from the traditional evaluation mechanism at college English classroom. And the guidance of teachers plays a key role in the evaluation. The process of mutual evaluation is also the process of learning and discussing with each other.

In short, the use of formative evaluation instead of the result evaluation is the basic principle of the ESP classroom effective evaluation mechanism; the open questions should be used instead of the objective questions to test the 
students' understanding and mastery. The teacher should give the students the initiatives of classroom evaluation while offering the main guidance.

\section{B. ESP Teaching Mode Construction Based on the POA}

Through the analysis of relevant factors, the author combs the important factors in the construction of ESP teaching mode and provides the basic ideas for the construction of teaching mode. Based on the POA, combined with the author's ESP teaching practice, the author analyzes the teaching concept, teaching hypothesis and teaching process in ESP teaching, and takes the ESP teaching of textile engineering as an example to construct the ESP teaching mode. As is shown below:

TABLE 2: ESP TEACHING MODE CONSTRUCTION BASED ON THE POA

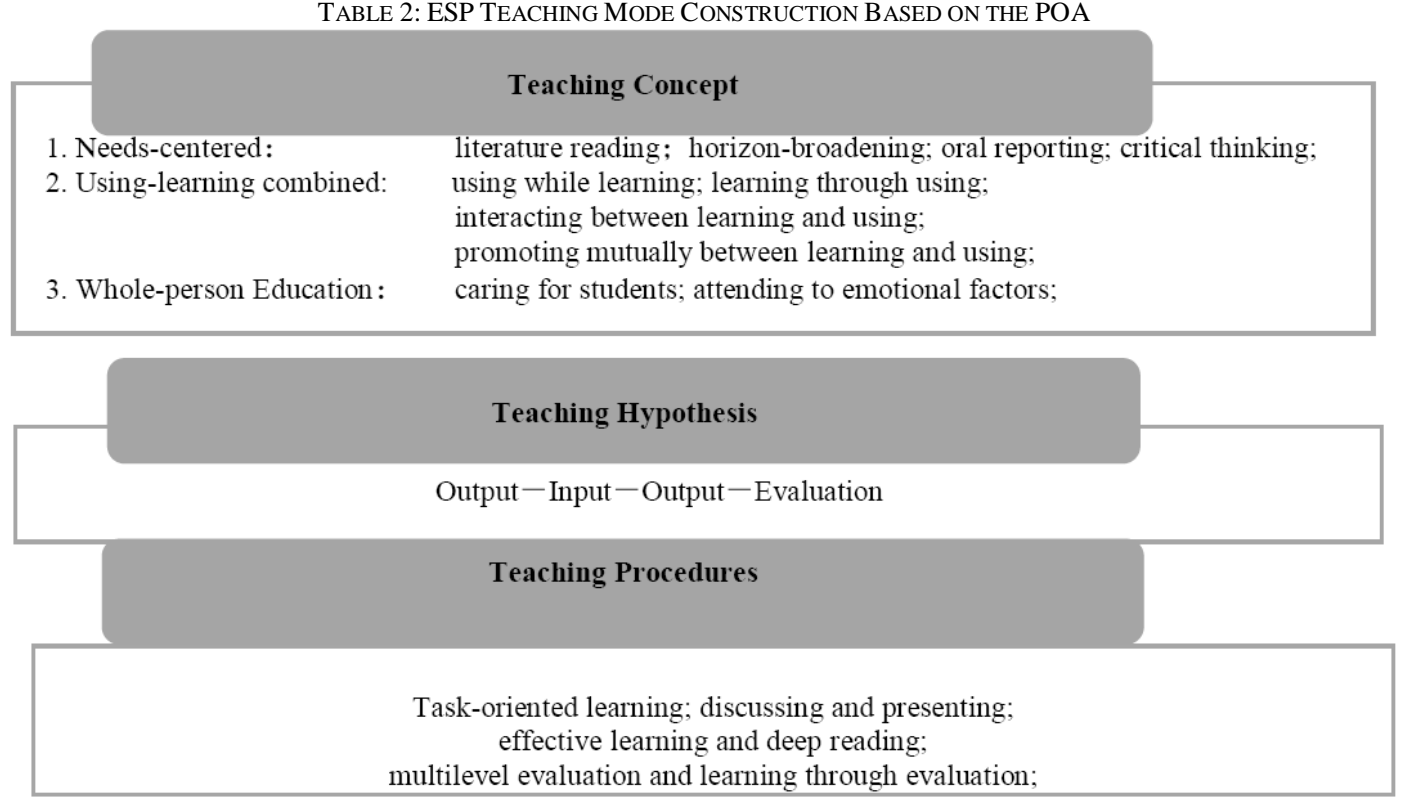

\section{Concepts, Assumptions and Processes of Mode Construction}

This part mainly introduces the specific elements related to the teaching mode construction. The design concepts, assumption and process of mode construction will be specified in details.

1 Teaching Concepts: Demand-centered, Learning-using Combined, Comprehensive Education

It is clearly targeted at understanding the diverse needs of students, meeting those students' needs who are interested in learning through ESP courses, improving the reading ability of academic literature and taking English as the carrier of expertise production capabilities. The design of the ESP teaching mode is based on the results of the student's college English learning needs survey and is compliance with the disciplinary orientation of the internationalization of textile engineering at the university.

The concepts of learning by doing, doing by learning. learning and using, classroom learning with offline online learning is to be organically integrated in teaching practice. It is designed to use the output to verify the effects of input and apply the effective input to increase the depth and breadth of output contents.

Teachers are the leaders of classroom teaching and students are the main body of classroom activities. Teachers are committed to promoting learning through interaction, paying attention to students' learning emotions, treating students equally, caring for students. Meanwhile, teachers, with holistic education and comprehensive education as the ultimate idea, are expected to provide necessary academic and emotional support in a timely and effective manner in classroom teaching.

2 Teaching Hypothesis: Output-Input-Output-Evaluation

Wen Qiufang (2014) believes that output is both a motivation for language acquisition and a goal for language acquisition. In view of the English level of Chinese students, with production as the core, Wen Qiufang proposes a series of hypotheses: Production-driven hypothesis; output driving---input-producing hypothesis (Wen, 2014) and Production-oriented Approach (Wen, 2015).

In ESP class, the emphasis is placed on the student-centered and teacher-leading mode with a focus on improving efficiency and effective learning, which may directly indicate Whether the teacher is conducting effective teaching or not and whether the students are having active learning. When the knowledge-based content is emphasized, the teacher leads the teaching process, in which the input purpose and output requirements are clearly defined; when the practical content is the priority, the student-leading interaction is the main part of classroom learning. The combination of formative evaluation and summative evaluation makes the formative evaluation of the classroom more conducive to the 
immediacy dynamic and efficient evaluation (Graves, 2008). At the same time, the research shows that students' self-confidence can be greatly improved through students' self-evaluation and mutual evaluation (Cao, 2009; Xu, 2014).

3 Teaching Process: Task-driven, Discussion first, Effective Reading, Post-reading Learning

The teaching focus, teaching purpose and teaching methods of ESP courses are different from those of EGP courses. Therefore, the reading input of students under the guidance of teachers is the focus of classroom teaching. In the before-reading discussion, students may lead the output by various forms and purposes, such as the brainstorming, activating reading interest, encouraging expression, discovering the language and opinion omissions; taking reading as the"axis". Teachers may play the role of guidance and lead the students to read by probing into the questions. The output after reading may take the forms of topic discussion, speculative writing, and academic topic presentation. Students are encouraged to expand their ideas, group operations, and collaborate to complete a project. At the same time the teacher-leading evaluation with students' full participation is also a key part of teaching, where teachers guide students to carry out reflective self-evaluation and mutual evaluation, evaluation of learning, and internalization of knowledge.

\section{ANALYSIS AND DisCUSSION}

\section{A. Case Study of Teaching Practice}

The author has provided the "ESP Course for Textile Engineering" for the textile engineering majors of 2015 at Tianjin Polytechnic University. The course is in the form of English development course and is suitable for the sophomores of textile engineering who have passed the CET Band $4 \& 6$. The number of students who have selected the course is 32, and all the students have passed the CET Band 6. Through before-course investigations and interviews, 27 people are found to have plans to receive postgraduate studies home and abroad, hoping that English can be combined with disciplinary studies in the future. It is hoped that they can read academic literature, write academic papers, and participate in various academic workshops.

The course is taught for 16 weeks and the exam is in the last week. The author composes the lectures by himself, and most of the academic English articles for textile engineering are mostly selected from Yahoo/Google Scholar. The suggested textbook is Science and Technology English Course published by Tongji University Press. Two weeks is a teaching cycle with a total of 8 units in a semester. There is one topic with two articles in each unit, in which one is for intensive reading and another is for after-class reading. In-class teaching per week is 4 classes, the first 2 classes each week is for the before-reading discussion and output, the second 2 classes is the problem-guided interactive reading comprehension; then another 4 lessons of the second week is for reading and note-sharing, related topic discussion and project presenting.

Take the topic in the third week, for example, Interwoven globe: a show that reveals the fabric of power. This article, with moderate difficulty level, totaling 1,350 words, was selected from the international trade column of Guardian. The passage focuses on the history of international textile trade development and introduces the current trend of the international textile trade, especially the rapid development of China's textile trade. The idea in the article shares some similarities with some of the contents in the course of "Introduction to Textile Trade" in the following semester for the textile engineering students. therefore, the mastery of background knowledge is conducive to reducing language barriers in reading.

Based on the teaching concept of needs-centeredness, combination of learning and using, and whole-person education, the teaching hypothesis is driven by the concept that the output is the driving force, the input is the facilitator, and the input and output are mutually promoted through interactions. The classroom teaching process is as follows:

Before-reading, the teacher guided students to brainstorm and share their thoughts on any topic of the article about international trade/textile trade/Chinese textile trade/ Sino-U.S textile trade friction, etc.; the teacher helped students vividly and intuitively acquire relevant knowledge and understand the article through watching the English short film "Brief History Of Global Textile Trade"; students were expected to choose a topic and analyze the feasibility of completing the projects through group discussion and determine the division of work by the team leaders.

While-reading: interactive teaching of question-based reading. The teacher identifies 15 questions and guides the students to find the answers in teacher-student interaction, understand the meaning of the article, master the important details, and find out the logical problems or fallacies in the structure or expression of the article. These 15 questions cover the general meaning of the article, important details and the main difficult points in language.

After reading, students were expected to: 1) complete the study notes which include new language points, article summary, reading method summary, and beautiful sentence appreciation, etc.; 2) mutually evaluate the notes and find out the best one for sharing; 3) give the group project statement, make PPT, share on the stage, evaluate, interact with students, and evaluate in a peer-to-peer way.

In the final evaluation of the final exam, the daily performance scores account for 60 points, namely: 20 points for notes; 20 points for class presentation; 10 points for mutual evaluation among group members; 10 points for regular attendance; an extra 10 points for unique insights on the issues. The final exam is to submit a small paper, accounting for 40 points. Students are required to select their own topics of interest from the 8 units covered in this semester, complete a micro-dissertation independently which shares his own opinions with more than 800 words by digging into 
the literature. Students are asked to submit an electronic version (for network plagiarism check) and printing version. The author along with one teacher from the School of Textile completes the scoring.

\section{B. Students' Feedback and Teacher Reflection}

After the 16-week teaching period, the author designs a questionnaire and a group interview to evaluate the student's ESP course and the teaching mode. The questionnaire surveys the students' gains from the ESP course. The questionnaire is divided into 3 categories and a total of 18 questions, which respectively investigate the improvement of reading ability, the improvement of English skills and the improvement of academic reading and expression skills. The statistical results show that the highest proportion of items is: "My expertise has been expanded through ESP courses." Of the 32 questionnaires, 84\% chose"totally agree", which is followed by: "I am more confident in academic reports through Textiles ESP courses. "79\% of the subjects choose "totally agree"; the lowest option is: "I have improved my reading comprehension accuracy through the ESP course. The proportion of "strongly agree" is $24 \%$, which is basically consistent with the author's observation in the teaching process. There are two reasons for that:

1) The main teaching purpose of this course is not to improve the students' reading test scores by reading the articles.

2) 16 weeks of teaching, 8 intensive articles, 8 extensive reading articles, and the language input of the course is relatively small. In the future teaching, one must improve the amount of language input while taking into the effects account.

At the same time, some students were invited to conduct interviews. Here are some answers from students:

S1: During the past four semesters, except for the preparation for CET Band 4\& 6, I am just living off one's past gains and ruining my time. I feel very regretful for that. but this semester when I was expecting another unfruitful term, I chose this course. The harvest is really very big. I have never thought about expressing myself about my major in English. But now, I find out I could make it. I will continue to work hard and strive to express more freely and confidently.

S2: To be honest, this course is really difficult. It seems that it is the most difficult course I have ever had in my school days. It is completely different from the course which is just for passing the exam. I felt quite painful when I studied, but in retrospect, I have reaped a lot. I can also say something in my specialty in English. I am proud of myself.

S3: I had never heard the ESP course before I chose this class. I suspected that it would be as dull as the other English course. I begin to understand it a little after studying for one semester. In fact, I just wanted to get the credits at first, so I took my IELTS tests to the class. But later, I found out that there was still something meaningful in class. I can also force myself to practice my oral English and share my ideas on the stage. It's really stressful to do so, but I really learn something while looking back. It is the richest semester in the four semesters of college English class. Meanwhile, I find that my thoughts are a bit widened, and the critical thinking required by IELTS writing seems less challenging than before.

S4: To be honest, this class is too time-consuming, and it is too difficult to take the credits, but I believe that every point is earned by myself, not just drifting along, and I have not wasted the precious time. Previously, time flies when switching the phone and starting the games after class, however, since I take this class, I have to think about group discussion, write reading notes, complete tasks, and share on the stage. There is certainly some considerable strain from this course, but it is very fulfilling too. I am very excited to complete a task with my peers.

S5: This class taught me how to use foreign academic websites, and how to search for what I want. I can stand up and discuss some issues related to textile engineering. I feel I am powerful although I still know quite a little. In addition, I did not like the major of textile engineering for I felt that I might be a female textile worker as someone always make the joke. But now I learn that this is also a serious science and a promising major, my interest in my major gradually awakens and grows.

\section{CONCLUSION AND LimitATIONS}

Based on the concept of Prof. Wen Qiufang's POA theory, combining with the characteristics of ESP teaching and the author's teaching practice and research, this paper attempts to construct the ESP teaching mode for textile engineering based on the POA concept. Guided by this mode, the author verifies its effectiveness in the teaching practice. Through questionnaires and other research methods, it is found that it can effectively improve students' literature reading, oral reporting ability under the guidance of textile engineering ESP teaching.

This study has the following limitations: 1stly, the statistical methods were slightly single and simple; the number of survey samples was small in terms of the students' English needs survey in the early period and students' achievements' surveys and questionnaires in the late period; secondly, the disputes between ESP and EGP is the focus of debate in the field of college English teaching. there is a certain degree of uncertainty in the meaning of the research. There are still different voices from other experts who disagree although there are experts, such as Professor Cai Jigang, Professor Wen Qiufang, Professor Sun Youzhong, Professor Wang Shouren and other well-known scholars, who are strongly supporting the development of ESP curriculum; thirdly, due to the lack of professional ESP measurement forms, the scientific validity of ESP teaching is still in doubt; fourthly, the content in the ESP course cannot be deepened due to the lack of disciplinary background and knowledge. Sometimes, the discussion seems a bit superficial and lack of in-depth analysis and digging. 
Notes: Due to the space limitation, the data collected and analyzed cannot be shown in the paper.

\section{ACKNOWLEDGMENTS}

The research in this paper was supported by the Teaching Reform Project of Tianjin Polytechnic University: "A Study on the ESP Curriculum System of College English at TJPU under the Background of 'Double First-class' Construction-Taking Textile Engineering as an Example". (NO. 2017-3-31)

\section{REFERENCES}

[1] Bachman, L. F. (2010). Language Assessment in Practice. Oxford: Oxford University Press.

[2] Cao Qunying. (2009). Teacher's Role-positioning in Students' Network Autonomous Learning. Foreign Languages Journal, 6, 174-176.

[3] Cai Jigang. (2010). Enlightenment of ESP Teaching in Universities in Taiwan to the Reform of English Teaching in Mainland Universities. Foreign Languages and Foreign Languages Research, 6, 26-30.

[4] Cai Jigang, Chen Yuyang. (2013). Analysis of Specialized English Needs in the Background of Internationalization of Higher Education. The teaching of Foreign Languages, 5, 3-9.

[5] Cai Jigang. (2015). Review, Problems, and Tasks of Specialized English Teaching in China. Journal of Xi'an International Studies University, 1: 68-72.

[6] Cai Jigang. (2018). Rethinking the Beliefs and Ideas of English for Special Purposes-Review and Reflection on Foreign Language Education in Colleges and Universities in China in the 40th Anniversary of Reform and Opening-up. Foreign Language Research, 2, 42-47.

[7] Chen Jianlin. (2016). The Normal Change and Development in the Process of Foreign Language Education Informatization-Based on the Visualization of Education Informatization, Foreign Language Ethylene Teaching, 2, 3-9.

[8] Danielson, C. (2013). The Framework for Teaching Evaluation Instrument. http://danielsongroup.org. (accessed 10/1/2017)

[9] Fang Xiucai. (2017). Research on the Evaluation Framework of Foreign Language Teaching Effectiveness in the Information Age. Foreign language electrification teaching, 2, 26-32.

[10] Graves, K. (2008). The language curriculum: a social contextual perspective. Language Teaching, 23, 36-48.

[11] Guo Yanling. (2015). ESP and EGP relationship and ESP curriculum design. Journal of Hebei Agricultural University (Agricultural and Forestry Education Edition), 4, 85-89.

[12] He Kekang. (2014). Predict the Future Development of "Flipped Classroom" in China from the Essence of "Flipped Classroom". Electra-education Research, 7, 5-16.

[13] Hu Pingping. (2016). Case Study of Teacher Implicit Courses in College English Teaching. The teaching of Foreign Languages, $4,20-25$.

[14] Jordan.R.R. (1997). English for Academic Purposes: A guide and resource book for teachers. Cambridge: Cambridge University Press.

[15] Kong Deliang. (2014). The Construction of Dynamic Mechanism of College English Teaching-Research Status and Theoretical Thinking. Foreign Languages, 5,23-31.

[16] Kong Fanxia. (2016). Correlation study of the impact of ESP reading input on language tasks. Foreign language electrification teaching, 12,15-21.

[17] Liu Mei. (2013). Continuum Mode of Chinese College English Teaching Based on ESP Curriculum System, Foreign language electrification teaching, 1, 27-31.

[18] Liu Chongxi. (2016). Investigation and Research on College English Classroom Teaching Mode. Foreign Language Electrification Teaching, 4, 15-19.

[19] Ren Rongzheng. (2012). ESP teaching "5W+1H" Element Analysis. Foreign Languages, 2, 58-64.

[20] Sun Xianhong. (2017). ESP Flipped Classroom Design from the Perspective of Multi-literacy Training. Foreign language electrification teaching, 4, 38-42.

[21] Sun Youzhong, Li Liwen. (2011). CBI and ESP and the Direction of College English Teaching Reform in Chinese College English Majors. Foreign Languages Research, 5, 1-4.

[22] Wang Haixiao. (2004). Analysis of the needs and conditions in the design of personalized college English syllabus. Chinese Foreign Languages, 1, 21-26.

[23] Wang Junkai. (2015). Application and Development of Educational Information Technology in ESP Teaching. The teaching of Foreign Languages, 1, 62-66.

[24] Wang Shouren. (2010). Comprehensively and Accurately Implement the "College English Course Teaching Requirements", Deepen the Reform of College English Teaching. Chinese Foreign Languages, 2, 4-7.

[25] Wen Qiufang. (2012). Opportunities and Challenges for College English: Curriculum Perspective. Foreign Language Teaching and Research, 2, 283-292.

[26] Wen Qiufang. (2014). Driving Production-input-producing Hypothesis: an Attempt to Construct a Teaching Theory at the University Foreign Language Classroom. Chinese Foreign Language Education, 2, 3-12.

[27] Wen Qiufang. (2015). Constructing the Theoretical System of "Production-oriented Approach". Foreign Language Teaching and Research, 4, 47-58.

[28] Wen Qiufang. (2017). Chinese Characteristics of the Production-Oriented Approach. Modern Foreign Languages, 3, 48-54.

[29] Wu Wenquan. (2014). ESP teaching Reflection Based on the Phenomenon of "MOOC Class". Modern Educational Technology $12,57-63$.

[30] Xu Jinfen. (2014). Analysis of Peer Interaction in the Second Language/Foreign Language Classroom. Contemporary Foreign Language Research, 10, 31-36.

[31] Ye Ling. (2017). Research and Practice of College English Flipped Class in the Internet + Era. Foreign language electrification 
teaching, 3, 3-8.

[32] Yin Hesu, Yan Qigang. (2011). On the Relationship Between College EGP \& ESP-Concurrently on the New Round of College English Teaching Reform and Development Direction. Foreign language electrification teaching, 1, 9 -14.

[33] Zheng Yuqi. (2014). Investigation and Analysis of the Role of Teachers in Foreign Language Teaching in the Post-Method Era. The teaching of Foreign Languages, 1, 59-64.

[34] Zhao Changhan. (2017). Research on the Development Principles and Countermeasures of Career-oriented Interpreting Materials. Foreign language electrification teaching, 4, 60-65.

Jinzhu Zhang, Male, a lecturer at the School of Humanity of Tianjin Polytechnic University, Tianjin, China. His research interest lies in the Applied Linguistics and Language Testing Theory \& Practice. 